\title{
Discretion and Disparity of Judicial Decisions
}

\author{
Amiek Soemarmi ${ }^{1}$, Erlyn Indarti ${ }^{2}$, Pujiyono $^{3}$ \\ \{amiek_hk@yahoo.com¹, erlyn@ymail.com², pujifhundip@yahoo.com³ \\ ${ }^{1,2,3}$ Diponegoro University, J1.Prof.H.Soedarto, S.H., Tembalang, Tembalang, Kota Semarang, Jawa \\ Tengah 50275 Indonesia
}

\begin{abstract}
A judge embraces a paradigm that significantly influences how reality is perceived, having captured the meaning of reality will create a relationship between the judge itself as a paradigm follower with a comprehensible reality, which will create a methodology for solving the problems of that reality. Without realizing, the paradigm will affect a judge in applying discretion. The discretion applied by one judge to another will be different. The difference is based on the diversity of its paradigm; on the difference of the paradigm, then there will be the disparity in the judge's decision. The disparity of the judge's verdict occurs because of the paradigm of a judge that is embedded in himself. The paradigm of a judge will affect the extent to which discretionary constraints are applied, with the diversity of paradigms adopted by judges will lead to differences regarding the limits of the discretionary application resulting in disparities in judges' decisions. This study uses a paradigm study using qualitative research as the initial determinant in which the variable is dynamic, which is not always static. Post-positivism paradigm will guide the author in the translation of data obtained through interviews and other observations.
\end{abstract}

Keywords: Jurisprudence, Discretions, Judge's Paradigm

\section{Introduction}

The original form of Judicial Power as stipulated in Article 24 of the 1945 Constitution of the Republic of Indonesia is the power to exercise a judicial function for every legal matter brought by the parties to court. There are two forms of legal product issued by the court, among others: "verdict" and "determination." Decisions and declarations are pronounced in public hearings by a judge as a state officer authorized by law for the matters. The decision is the product of the judiciary in resolving disputes occurring in society, whether in private (civil and religious), or the relationships of the state with its citizens over violation of the rules of criminal law and administrative relationships between the government apparatus and the public over the issuance of a State administrative decision. Whereas in other functions, the court decision is also a legal institution in the process of legal education for the community, the principles contained in the considerations should reflect constructive values as a learning for the community, for example, prevention of applicable law by not excluding the application of local wisdom values applicable in each region.

In nowadays' reformation era, people seem to have the full right to appraise justice in every judge's decision. Thus, it is not surprising that people easily criticize and blame the judgment of the court without first understanding what the argument in the ruling is. The current paradigm that public support is more in favor of issues that are popular in the community by mass media and electronic media. The pressure can see this through the public opinion that makes the judges' mind to be easily disturbed in deciding a case. The position of the judge in giving the decision plays a vital role in the process of creating a disparity in the decision. The decision disparity created is a long-term result of the process of discretion. Disparities in the verdict do not just happen without a clear basis. Each judge will have his or her view of the extent of discretion. However, the limits to applying this discretion are highly 
dependent on the paradigm of someone who embraces it. Purnadi Purbacaraka and Soerjono Soekanto argue that judges have free discretion, their feelings about what is right and what is wrong is the real direction to achieve justice.[1]

According to the Law Number 48 of 2009 Article 18, Judicial Power shall be exercised by a Supreme Court and subordinate courts within the courts of the General Courts, Religious Courts, Military Courts, and State Administrative Courts, and by a Constitutional Court. The Supreme Court is the highest judicial institution in Indonesia. Other than being a supervisory body of the four courts under it, the Supreme Court is also the final wall for the seeker of justice, while the Constitutional Court is the first and final judicial institution for constitutional disputes as mentioned in Article 24 paragraph (1) of the 1945 Constitution of the Republic of Indonesia.

At this time, there has been known of several special courts in the development of constitutional law, both fixed and ad hoc, among others, namely: 1) Human Rights Court; 2) Court of Corruption; 3) Commercial Court; 4) Juvenile Court; 5) Fisheries Court; 6) Industrial Labor Court; 7) Tax Court.

The existence of special courts established within a court environment makes the structure within the judiciary becomes more complex, and this may affect the quality of human resources who play a role in law enforcement, especially in court hearings, which have career judges and ad hoc judges in special courts under global justice.[2]

The Supreme Court, other than being the highest judicial institution in seeking justice, it also has a role as an institution that has supervisory and nurturing functions for the judicial bodies under it. In the case of carrying out the supervisory functions, the Supreme Court shall not limit the independence of judges in judging of a case. The freedom of Judges at all levels is the same. The higher-level body of justice can only correct the judge's decision on the lower courts to the extent that it involves a re-examination in the case of a remedy.

Discretionary action given positivism (legalism) can be qualified as a violation of the law (legalistic defiance) or abuse of power since the agency/government performs the conduct. In this context, a broad conceptual spectrum is required in explaining the nature of the concept of discretionary powers of government to gain an understanding of the essence of discretionary powers from the perspective of the law.

Theoretically, the source of discretion is: express and implied statutory provisions, the form of discretionary power, and royal prerogative. Today, the scope of the concept of discretionary tends to narrow down due to the strengthening demands of the Rule of law (Principle of Legality). However, the essential scope of the concept of discretion has always been under the dictates of the law, so that the development of this concept need not be worried much. Discretion is a legal concept; therefore, the law would never have let discretionary powers be out of legal control.

Discretionary powers of the government can be justified morally based on the foundation of Natural Law, which validates the power of the government to rule over its citizen. The concept of Natural Law itself is universal and can be applied anywhere and anytime. Inherent to the limitation on the discretion means inherently complies with the appropriate source of validity, which is the dictation of Natural Law itself. Discretion also has relevance to the purpose of the law. In line with discretion within the framework of legal purpose, the agency/government officials who carry out acts of discretion should be aware that the discretionary measure will be assessed or tested by standards of morality in which it is based.

The principle of equity reflects moral quality, which allows individuals to conform to the provisions of the law strictly. Discretionary powers of government are legitimate by the principles of equity-because there are cases when the government should take discretionary 
action reflecting equitable approach in law. The principle of equity does not specify a definitive prescription for discretionary action but put the evaluative framework consisting of good faith, honesty, and generosity.

The paradigm of a person does not only show a person's mindset, perspective on reality, in this case, the law he faces. Furthermore, someone's paradigm also shows the relationship that occurs between the man himself and the reality he faces. Rising at a further level, there will be patterns that produce ways to solve the problem of the faced reality, and the absolute final stage will be found in every living and intelligent human.

Towards the judge's verdict, there are often differences or disparities. Disparities occur because of the underlying differences. One of the differences is caused by the paradigm of judges that is embraced. Therefore, the judge's paradigm relates and influences each other in doing the discretion before the case is terminated until there is disparity done by the judge after a decision is dropped. Thus, the problems in this writing are how discretion and disparity in the judge's decision can be understood through the paradigmatic study.

\section{Methodology}

This research method is essentially a scientific way of getting information as it is, not as it should be. Most of the verified data is not as expected. In order to get scientific research result, it requires the scientific method as well. This research requires accurate data, including primary data and secondary data. The data is obtained through the research method. Primary data is obtained from field research through direct observation of phenomena or social phenomena studied by conducting interviews with the key informant, while secondary data derived from library research which licensed material is derived from primary and secondary legal materials. Primary materials derived from legal materials that have binding power such as law or court decisions, and secondary legal materials through legal materials that provide explanations of primary legal materials. Other than tertiary legal materials, that is all legal materials that explain the primary and secondary law.

These data, both primary and secondary data, have been collected by qualitative analysis so that the authors will collect, draw the logical lines into individual bonds. The existing data based on data entered or obtained is processed in such a way by examining and tested the truth. This study rests on the understanding of the paradigm of Guba and Lincoln (1994). By using paradigm study, it will guide in understanding the philosophical problems of law, where this study sees the law as relative and contextual, that the consensus is a relative and contextual agreement. Through a paradigm study, the authors examine some judges' rulings in the Fisheries, Juvenile Court, Commercial Court and other Special Courts where all are special courts under the general judiciary

\section{Findings}

\subsection{Judge Paradigm in practices}

Judge, as the last pillar in which law is depicted working on the functioning of a judicial system, is considered a person who is obliged to have a living and functioning conscience. The judge is always challenged to defend the case or problem he faces continuously conscientiously. The inherent paradigm of the judge will determine the extent to which the conscience can participate in understanding the legal reality at hand. Positivism adherents, for example, will ignore the factor of "conscience" in them to be involved in cases or problems 
that are faced.

On the other hand, external factors from outside the judge, such as the excellent working environment where all the origins of the case are processed to produce a final decision, family environment, culture and other environments that show a situation emphasizing on the location or word that indicates the place will be strongly influenced by the paradigm of what the judges hold. Paradigm will determine how far this factor is enough to affect a reality seen and placed. Post Positivism adherents become a real characteristic where environmental factors are very prominent in the mindset. Post Positivism adherents will bring a cultural factor that guides to see reality so that it is no stranger to the term "institutional mental attitude" which shows a result of the strong influence of a culture in a particular environment.

A judge, in performing judicial duties, is restricted by law. However, that does not mean that a judge is a funnel of laws that only impose and enforce the law as long as the law can provide justice. When the law cannot provide justice and will cause injustice, then the judge must dare to act to deviate. A judge must dare to step out of the paradigm that deviating from the law is a sin, and a judge must dare to shift to the paradigm that disregarding the believed justice is the real big sin because the fundamental foundation in deciding cases is "By Justice" not "By Law."

Judges are often faced with a difficult choice that is between justices with legal certainty that cannot be united in a conclusion. The two principles ideally can be juxtaposed in a verdict but integrating justice, and legal certainty is not comfortable in reality.[3] A judge is appointed and dismissed by the President by a decision letter. In addition to carrying the mandate of the law, a judge is also an extension of God's hand to uphold truth and justice based the freedom of a judge in deciding a case is protected by law. Any form of act or behavior that is insulting, degrading and influencing the judicial institution, either directly or indirectly in its function and duty to uphold law and justice is a violation of the law and a contempt of court.[4] Law Number 48 The year 2009 in Article 3 Paragraph (2) states that "any interference in the affairs of the judiciary by any other party outside the judicial authority is prohibited except in the case referred to in the 1945 Constitution of the Republic of Indonesia". Furthermore, paragraph (3) stated: "Any person who knowingly violates the provisions of the law shall punish the provisions referred to in paragraph (2).

Judicial discretion can be defined as a result of its exercise is referred as the discretionary decision is exercised when the judge is granted power under statutory discretion in common law that requires the judge to choose between several different, but equally valid, courses of action.[5]

There is no or less clear law regarding the consequences of the prohibition of a judge from rejecting the case for an examination on the grounds. The judge is equipped with the authority to interpret the law, while interpretation is a reasoning process aimed at 1) Understand the meaning of the principle or the rule of law; 2) Linking a legal fact to the rule of law; 3) Ensure the application or enforcement of the law can be done appropriately; 4) Meeting between the rule of law and social changes so that the rule of law remains actual and is able to meet the needs in accordance with the change of society.[3]

The provision of Article 7 of Law Number 2 of 1986 as already amended by Law Number 49 of 2009 concerning General Court, the judge is asked to swear an oath/position. Judge is a State Official who has the mandate to uphold justice based on the One Supreme God. The concept of authority to judge is the embodiment of the provisions of Article 1 paragraph 3 of the 1945 Constitution of the Republic of Indonesia which states that the State of Indonesia is a State of law, so the law should be a guide in the life of the nation and state. In line with the concept, the Supreme Court, with four judicial circles under it is in charge of performing the 
functions of justice and upholding the law. The responsibility of the judge to the nation and the State is also reflected in the oaths pronounced before taking office, which is carrying out his duties he must be loyal to Pancasila and the 1945 Constitution of the State of the Republic of Indonesia.

Furthermore, about the authority of interpretation, a judge faces several matters, among others: First, the judge must decide upon the law. Each decision must be based on specific legal rules that existed at the time a legal event occurred (not when the decision is to be made). Second, judges are prohibited from refusing to decide upon reasons of unavailability of existing rules of law or unclear rules. Third, the judge must decide quickly, based on the phrase that says justice delayed, justice denied".[3]

A judge shall settle any legal dispute submitted to him wisely and prudently, following the legal jurisprudence that applies according to the rules of positive law and the living conditions of society. Judges are required to explore and understand the values and norms that live and thrive in a legal community alliance. The law should not be interpreted as a law only, but the law is a manifestation of all forms of ethical rules that have been legitimated by the power of the State and which are still in the form of norms, which are scattered in the social life of the community. It is as stated by Satjipto Rahardjo, cited from a book of that there are always some weaknesses in the law, among others: 1 . It is rigidity. This shortfall immediately appears in connection with the will of the legislation to show certainty. If the certainty is to be fulfilled, he must pay it by making clear and detailed formulations with the risk of becoming rigid norms; 2 . The desire of legislation to make general formulas carries the risk that it ignores and thereby violates specific differences and characteristics which cannot be generalized. Especially in this complex and specialized atmosphere of modern life, it is not easy to make the placement (generalization)

\subsection{The Definition of Discretion and Disparity in Judicial Decision}

The position of the fishery court, as a special court under a public court, has career judges and ad hoc judges, where not all have the legal background and are vulnerable to interpretations that are inconsistent with the rules of procedural law, although technically have expertise in fisheries. On the other hand, career judges have the knowledge and experience of event legal and understand the rules of law well, but they do not have technical expertise in the field of fisheries. This would have the possibility of raising multiple interpretations between judges in understanding the case and would have implications for improper judicial/sanction verdict. This is due to the discretion and disparity that the judge has in giving the verdict.

When law enforcement is dealing with a case or problem that exists in the community, independence and authority or authority inherent in itself allows the ability to perform different kinds of work wisely and considerately at once, i.e.:[6]

1. Read the case or problem well.

2. At the same time, translating the existing law comprehensively. This is especially true in some cases that can be directly done in black and white,

3. In most other cases, it is often necessary to interpret the translated law further. When the works collide with each other. The next work to do is:

4. Sort out both the read case and the law that has been translated and or interpreted

5. Selecting and setting options. Thus, are two more second-line jobs that are expected to be enforced by a law enforcer when dealing with a case or problem. As for the two of the third or last part jobs that immediately follow the choice as mentioned above are: 
6. Make a decision or conclusion

7. Take specific actions or steps.

Thus, for a law enforcer, in the execution of his duties, decisions that are made or whatever steps taken have gone through a long process with full "professional judgment." The whole set of processes that take place within a relatively wide range of space is what is said to be discretion.

Some definitions of discretion:[6]

Oxford: the Australian reference Dictionary (1992) defines discretion as:

"Freedom of authority of a person to act according to the judge."

Oxford: Advanced Learner's Dictionary (2010) defines discretion as follow:

"The freedom or power to decide what should be done in a particular situation."

Meanwhile, Collins Dictionary and Thesaurus (1991) describe discretion with a slightly different definition, that is:

"Freedom or authority of a person to make a judgment and to act as he considers appropriate (or fitting, proper, worthy or suitable)."

While according to the English-Indonesian dictionary by John M Echo's and Hasan Shadily, the definition is:

"Kebijaksanaan, keleluasaan atau kebebasan untuk menentukan atau memilih (Wisdom, discretion, or freedom to decide or to choose)."

By considering the above exposure, there are at least 8 (eight) elements that can be identified and all its derivative meaning contained in the definition of discretion, i.e:[7] 1) Independence, 2) Authority, 3) Wisdom, 4) Choice, 5) Decision, 6) Act, 7) Exactness, 8) Accountable

The eight elements above are formulated comprehensively and conclude that discretion is:[7]

"Independence and authority (a person/group of people/or institutions) to - wisely and considerately - make choices in terms of making decisions and or taking (particular) action which is deemed most appropriate."

Decision-making and action-taking above are mostly the ends of a long sequence of processes. The process involves the outpouring of wisdom which in this case also includes precautionary based on adequate intellect or skillfulness. The process also involves consideration or assessment from all points of view somewhat. Only then comes the choice of decision-making and taking specific actions. In the case of law enforcement, for example, the whole process can be understood as a series of efforts.[7] Reviewing the case at hand, 2) Read the existing (legal) terms, 3) Interpret such provisions further, 4) Sort out existing provisions as needed, 5) Select or set options, in the case of, 6) Make a legal decision, and 7) Take specific legal steps or actions.

The disparity of sentencing is the application or imposition of different criminal sanctions and felt as unfair tendentious by some parties without a rational and discriminatory legal basis. The imposition of different criminal sanctions is committed against offenses punishable by the same criminal or criminal penalties, while criminal disparity is the unequal application of criminal offenses to the same criminal offense or to criminal offenses which the dangers are comparable without clear justification ground [8] put this definition forward. According to Harkristuti and Harkrisnowo disparities can occur in several categories namely: 1) Disparity between the same criminal acts; 2) Disparity between criminal acts that have the same seriousness; 3) Criminal disparity imposed by a panel of judges; 4) Disparity between the criminal sanction imposed by different judges for the same offense.

Legal factors that cause criminal disparity, among others, are because in the positive law in 
Indonesia, judges are given freedom and are allowed widely to determine the type of criminal. While for other factors, Muladi states that in addition to things that come from the law, there are other things that cause the disparity in which the factors derived from the judges themselves, both internal and external that cannot be separated because it has been billed as an attribute of a person called human equation or personality of the judge, which in the broad sense is the influence of social background, religious education, experience, and social behavior. The matters above often play an essential role in determining the type and severity of punishment rather than the nature of his actions and the personality of the perpetrators of the crime.

Oemar Seno Adji views that punishment disparity is a justification, provided that disparity is based on clear and justifiable reasons. This view is in line with the principle of a judge's freedom in judging the case brought against it. This view is a form of reflection where the judge in his effort to keep the authority of law, must be able to justify the resulted decision by giving a correct and reasonable reason about the case examined. If it is logical, then the criminal disparity will be accepted by the community without disturbing satisfaction society against judges' ruling and also will not damage the sense of justice living in society.[9]

In every state, there is no legal system that can survive in any society without an acceptable degree of judicial discretion.[10]There must be a judicial discretion in many ways might be occurred. As a comparison, in the universal law system, the judicial system designed in a manner that certain limitations are always in the way of the court, to define, refine, qualify, and regulate to exercise of such powers.[11]

\section{Conclusion}

The discretion applied by one judge to another will be different, where the difference is based on the diversity of the paradigm he/she holds. On the difference of the paradigm, there will be the disparity in the judge's decision. The disparity of the Judge's Decision is due to the paradigm adopted by the judge himself. The diversity of the paradigm adopted by the judge will cause differences regarding the limits of the application of discretion, thus producing disparity in the judge's decision.

This is possible considering that the Judicial Power, under Law Number 48 of 2009 Article 18 , is conducted by a Supreme Court and its subordinate courts within the environment of the General Courts, Religious Courts, Military Courts, and State Administrative Courts and by a Constitutional Court. The principle of law serves as a fundamental basis for the legal system. Legal principles mostly have the same capability as the rule of law in prescribing specific action. The general principle of law is essential to justify the discretionary powers of government to build a shared understanding of the concept of discretionary powers of government. To qualify as the legal power, the discretionary power must also be justified by the "law," which in this case are the general principles of law.

The issue of justice emerges when discretion is associated with a reason to achieve public goods. Discretionary government action should avoid injustice, particularly in matters relating to public goods as a basis for the implementation of discretionary measures. In interpreting what constitutes public good, the government needs to consider the achievement of the optimum balance between individual and collective needs.

\section{References}

[1] S. Soekanto and P. Purbacaraka, Renungan Tentang Filsafat Hukum. Jakarta: 
Rajawali, 1982.

[2] A. Soemarmi, "Pembentukan Pengadilan Perikanan Sebagai Upaya Pelaksanaan Penegakan Hukum di Bidang Perikanan," Diponegoro, 2012.

[3] B. Manan, "Beberapa Catatan Tentang Penafsiran," Varia Peradilan, Jakarta, p. 285, 2009.

[4] I. Seno Adji, Humanisme dan Pembaharuan Penegakan Hukum. Jakarta: Kompas, 2009.

[5] A. C. J. Miles, B. J. Perry, and C. J. Kirby, "Judicial Discretion and Human Rights: Expanding The Role of International Law in Domestic Sphere," Melb. J. Int. Law, vol. 5, no. June, pp. 4-6, 2003.

[6] E. Indarti, Diskresi dan Paradigma. Semarang: Badan Penerbit Undip, 2010.

[7] E. Indarti, Diskresi Kepolisian. Semarang: Badan Penerbit Undip, 2000.

[8] Muladi and B. N. Arief, Teori dan Kebijakan Hukum Pidana. Bandung: Alumni, 2009.

[9] O. Seno Adji, Hukum-Hukum Pidana. Jakarta: Erlangga, 1984.

[10] R. G. Maclean, "Judicial Discretion in the Law of Torts," Harv. Law Rev., vol. 35, no. 1, p. $68,1921$.

[11] A. A. Kana, "Perspectives and Limits of Judicial Discretion in Nigerian Courts," $J$. Law, Policy Glob., vol. 29, no. 157-167, pp. 157-168, 2014. 